\title{
PENGEMBANGAN PERANGKAT PEMBELAJARAN IPS BERBASIS MODEL LEARNING CYCLE $7 E$ UNTUK MENINGKATKAN AKTIVITAS DAN KETERAMPILAN BERPIKIR KRITIS SISWA KELAS IV SEKOLAH DASAR
}

\author{
${ }^{1}$ Evi Kurniasih, ${ }^{2}$ Aminuddin Kasdi, ${ }^{3}$ M.V Roesminingsih \\ ${ }^{1}$ Mahasiswa Program Pascasarjana, Prodi Pendidikan Dasar, Universitas Negeri Surabaya, \\ ${ }^{2 \& 3}$ Dosen Pascasarjana, Prodi Pendidikan Dasar, Universitas Negeri Surabaya \\ e-mail: veezasmart19@gmail.com
}

\section{Received : Juli 2017}

Reviewed: Agustus 2017

Accepted : September 2017

Published : September 2017

\section{ABSTRACT}

This research aims to produce learning instrument based models eligible $7 E$ Learning Cycle is used to increase the activity and critical thinking skills of the fourth grade students of elementary school. Learning instrument are developed, namely: RPP, LKS, BAS, LPAS, and TKBK. Design of a test using one group pretest-posttest design are exercised is limited to 10 fourth grade students of SDN 1 Karangsalam then tested on a test implementation of the 21 fourth grade students of SDN Piasa Wetan academic year 2015/2016. The results showed: (1) the validity of the learning instrument that includes RPP, LKS, BAS, LPAS, and TKBK valid category; (2) learning instrument that have been developed practically used as indicated by $100 \%$ and the category of practically is excellent category by 3.63 , the result of a positive student response and legibility BAS and LKS within easy categories; and (3) the effectiveness of the learning instrument shown by an increase in activity and critical thinking skills of students. Activities of students before the learning category of moderately active after learning increases become active and very active categories. Increased critical thinking skills of students with the average value of n-gain is 0.72 in the high category. Based on the results and discussion of this research concluded that social studies learning instrument based $7 E$ Learning Cycle model has met the eligibility criteria, namely learning instrument validity, practicality, and effectiveness can increase the activity and critical thinking skills of the fourth grade students of elementary school.

Keywords: Learning instrument, learning cycle $7 e$ model, activity, critical thinking skills.

\section{ABSTRAK}

Penelitian ini bertujuan untuk menghasilkan perangkat pembelajaran berbasis model Learning Cycle 7E yang layak digunakan untuk meningkatkan aktivitas dan keterampilan berpikir kritis siswa kelas IV sekolah dasar. Perangkat pembelajaran yang dikembangkan yaitu: RPP, LKS, BAS, LPAS, dan TKBK. Desain uji coba menggunakan one group pretest-posttest design yang diujicobakan secara terbatas pada 10 siswa kelas IV SDN 1 Karangsalam kemudian diujicobakan pada uji implementasi kepada 21 siswa kelas IV SDN Piasa Wetan tahun pelajaran 2015/2016. Hasil penelitian menunjukkan: (1) kevalidan perangkat pembelajaran yang meliputi RPP, LKS, BAS, LPAS, dan TKBK berkategori valid; (2) perangkat pembelajaran yang telah dikembangkan praktis digunakan yang ditunjukkan dengan keterlaksanaan RPP sebesar 100\% dan kategori keterlaksanaan RPP sangat baik sebesar 3,63, hasil respon siswa positif serta keterbacaan BAS dan LKS dalam kategori mudah; dan (3) keefektifan perangkat pembelajaran ditunjukkan dengan adanya peningkatan aktivitas dan keterampilan berpikir kritis siswa. Aktivitas siswa sebelum pembelajaran kategori cukup aktif dan setelah pembelajaran meningkat menjadi kategori aktif dan sangat aktif. Peningkatan keterampilan berpikir kritis siswa dengan nilai rata-rata $n$-gain sebesar 0,72 dalam kategori tinggi. 
Berdasarkan hasil dan diskusi penelitian dapat disimpulkan bahwa perangkat pembelajaran IPS berbasis model Learning Cycle 7E telah memenuhi kriteria kelayakan perangkat pembelajaran yaitu kevalidan, kepraktisan, dan keefektifan yang mampu meningkatkan aktivitas dan keterampilan berpikir kritis siswa kelas IV sekolah dasar.

Kata-kata Kunci: Perangkat pembelajaran, model learning cycle 7e, aktivitas, keterampilan berpikir kritis.

\section{PENDAHULUAN}

Indonesia sebagai bagian dari dunia yang kini memasuki abad ke-21 yang ditandai semakin pesat perkembangan IPTEKS dan globalisasi di segala bidang, maka tantangan peningkatan mutu di berbagai aspek kehidupan tidak dapat ditawar dan salah satunya pada aspek pendidikan. Setiap bangsa di dunia, khususnya Indonesia dituntut untuk mengerahkan potensi sumber daya manusia yang dimilikinya serta memiliki kecakapan berpikir dan belajar abad 21. Husamah \& Setyaningrum (2013:188) menyebutkan kecakapan-kecakapan tersebut diantaranya kecakapan pemecahan masalah (problem solving), kecakapan berpikir kritis (critical thinking), kolaborasi (collaboration), kecakapan berkomunikasi (communication), dan kecakapan kreativitas dan inovasi (creativity and innovation). Keterampilan berpikir kritis merupakan salah satu dari kecakapan yang perlu dikembangkan dan ditingkatkan sejak dini terutama jenjang persekolahan dasar.

Paradigma pembelajaran abad 21 menekankan kepada kemampuan siswa untuk berpikir kritis, menjadi pebelajar selamanya, mampu menghubungkan ilmu dengan dunia nyata siswa, menguasai teknologi informasi dan komunikasi. Diperkuat oleh Muijs \& Reynolds (2008:185) yang menyatakan bahwa selama beberapa tahun terakhir ini ada penekanan yang semakin besar pada pengajaran keterampilan berpikir yang disebabkan oleh adanya berbagai perubahan di masyarakat, khususnya perubahan yang bergerak ke arah masyarakat di mana pengetahuan dan informasi menjadi semakin kompleks dan semakin cepat membludak yang berarti bahwa memproses sejumlah besar pengetahuan saja tidaklah cukup.

Empat dimensi keterampilan IPS dalam proses pembelajaran yaitu keterampilan meneliti, keterampilan berpikir, keterampilan partisipasi sosial, dan keterampilan berkomunikasi (Sapriya, 2012:51). Keterampilan berpikir merupakan salah satu modal yang harus dimiliki siswa sebagai bekal dalam menghadapi perkembangan ilmu pengetahuan dan teknologi pada masa sekarang ini (Dwijananti \& Yulianti, 2010:111). Semua keterampilan dalam pembelajaran IPS ini sangatlah diperlukan dan salah satunya adalah melatih siswa untuk belajar berpikir, yaitu berpikir kritis. Keterampilan berpikir kritis adalah pemikiran yang reflektif dan masuk akal yang berfokus untuk memutuskan apa yang mesti dipercaya atau dilakukan (Ennis, 1985:45). Jadi keterampilan berpikir kritis akan mempengaruhi hidup seseorang karena keterampilan berpikir kritis berperan dalam hal membuat keputusan yang dapat dipertanggungjawabkan dan dapat dipercaya.

Berpijak dari keseluruhan pemaparan di atas, jelas adanya tuntutan dari pendidikan nasional, tuntutan abad 21, dan tuntutan dari IPS itu sendiri sebagai mata pelajaran mengisyaratkan bahwa siswa haruslah dibina dan dipersiapkan untuk menjadi warga negara yang baik, bertanggung jawab, dan mampu berpikir kritis serta logis mengantisipasi berbagai perubahan yang tidak menentu yang terjadi di masyarakat.

Para pengajar IPS di sekolah umumnya masih menekankan pada tujuan pemahaman kognitif yakni bagaimana siswa dapat memahami konsep dan materi sehingga siswa dapat mengerjakan ujian baik sekolah maupun nasional, yang notabene masih menekankan pada hafalan belaka dan kurang melatihkan keterampilan berpikir kritis yang justru kelak akan menjadi bekal hidup siswa untuk mengarungi kehidupannya. Hal ini dipertegas oleh Sanjaya (2006: 226) bahwa salah satu kelemahan proses pembelajaran yang dilaksanakan para guru kita adalah kurang adanya usaha pengembangan kemampuan berpikir siswa.

Berdasarkan observasi yang telah dilakukan, proses pembelajaran IPS pada umumnya masih didominasi oleh guru, guru cenderung mengajarkan IPS masih dengan metode konvensional dan penyampaian materi masih bersifat verbalistis. Siswa diarahkan kepada kemampuan untuk menghafal dan menerima berbagai informasi yang diingatnya dan tanpa menghubungkan informasi tersebut dengan kehidupan sehari-hari sehingga hal tersebut menjadikan siswa jenuh dan sulit untuk menerima materi yang disampaikan oleh guru serta aktivitas belajar siswa masih rendah.

Keterampilan berpikir kritis siswa tidak hanya dipengaruhi oleh ketidakmampuan siswa dalam menggunakan pengetahuan yang sudah siswa miliki namun 
juga dipengaruhi oleh kemampuan guru dalam persiapan dan perencanaan KBM. Belum adanya perangkat pembelajaran yang dikembangkan khusus untuk meningkatkan keterampilan berpikir kritis siswa yang layak dan memadai sangatlah berperan dalam menentukan keberhasilan KBM. Oleh karena itu pentingnya inovasi dalam pembelajaran sangat diperlukan dalam proses pendidikan saat ini dan salah satu solusi dari permasalahanpermasalahan di atas adalah pembelajaran IPS berbasis model pembelajaran Learning Cycle $7 E$ yang diupayakan dapat membuat siswa lebih aktif terlibat dalam proses pembelajaran. Dengan mengikuti setiap proses pembelajaran IPS berupa interaksi dalam KBM sesuai ketujuh fase dalam model Learning Cycle $7 E$ dan mengajukan cara-cara penyelesaian dari suatu masalah sosial yang diberikan maka keaktifan siswa tersebut dapat terwujud. Melalui keterlibatan siswa secara aktif dalam proses pembelajaran maka diharapkan keterampilan berpikir kritis siswa dapat terlatih dengan baik.

Penelitian yang dilakukan Hartono (2013) menunjukkan bahwa peningkatan berpikir kritis siswa dapat dipengaruhi oleh proses pembelajaran sehingga terjadi peningkatan yang signifikan terhadap keterampilan berpikir kritis, aktivitas bertanya pada guru, dan keseriusan dalam melaksanakan tugas dari siklus pertama ke siklus kedua pada mata pelajaran IPA. Model ini dapat mengorganisasikan tugas-tugas siswa yang diberikan oleh guru. Learning Cycle merupakan rangkaian tahap-tahap kegiatan yang diorganisasi sedemikian rupa sehingga siswa dapat menguasai kompetensi-kompetensi yang harus dicapai dalam pembelajaran dengan jalan berperan aktif (Lawson, 1995:136).

Tujuan dalam penelitian ini adalah untuk menghasilkan perangkat pembelajaran IPS berbasis model Learning Cycle $7 E$ untuk meningkatkan aktivitas dan keterampilan berpikir kritis siswa kelas IV sekolah dasar yang layak untuk diimplementasikan.

\section{TINJAUAN PUSTAKA}

\section{A. Perangkat Pembelajaran yang Layak}

Nieveen (1999:128) menyatakan bahwa perangkat pembelajaran yang layak haruslah memenuhi kriteria kelayakan perangkat pembelajaran yang meliputi validitas, kepraktisan, dan keefektifan. Kriteria valid apabila perangkat pembelajaran yang dikembangkan memenuhi validitas konstruk dan validitas isi serta perangkat pembelajaran yang dikembangkan berkategori valid. Kepraktisan adalah bahwa perangkat pembelajaran yang dikembangkan mempertimbangkan kemudahan yaitu perangkat pembelajaran mudah untuk dipahami dan keterlaksanaan RPP berkategori baik serta adanya respon positif siswa dan keterbacaan BAS dan LKS mudah. Sedangkan keefektifan perangkat terlihat pada ketercapaian tujuan pembelajaran yang dilakukan oleh siswa berupa peningkatan aktivitas dan keterampilan berpikir kritis siswa (Rajabi et al., 2015:49).

Pada penelitian ini, perangkat pembelajaran yang dikembangkan adalah Rencana Pelaksanaan Pembelajaran (RPP), Lembar Kegiatan Siswa (LKS), Lembar Penilaian Aktivitas Siswa (LPAS), dan Tes Keterampilan Berpikir Kritis (TKBK).

\section{B. Model Pembelajaran Learning Cycle $7 E$}

Model pembelajaran yang digunakan guru ada yang menggunakan simbol siklus, lingkaran, segitiga, dan bujur sangkar. Secara umum simbol tersebut mempresentasikan fase ataupun tahapan suatu model pembelajaran yang meliputi eksplorasi tidak terstruktur, berbagai program pengalaman belajar, dan arahan yang bersifat didaktis (Hawkins dalam Bybee et al., 2006:6). Salah satu model pembelajaran berbentuk siklus yang terdiri dari beberapa fase adalah model pembelajaran Learning Cycle. Learning Cycle (siklus belajar) merupakan suatu model pembelajaran yang berpusat pada siswa. Model ini melalui tahapan-tahapan pembelajaran yang dapat memberikan perhatian pada konsep, melakukan penyelidikan, memberikan penjelasan, melakukan evaluasi, dan mengaplikasikan konsep ke dalam situasi yang baru (Bybee et al., 2006:3).

Learning Cycle pertama kali diperkenalkan oleh Robert Karplus dan Myron Atkin di tahun 1970 dalam Science Curriculum Improvement Study (SCIS) yang pada awalnya terdiri dari tiga fase yaitu exploration, invention, dan discovery (Trowbridge \& Bybee, 1990:306; Lawson, 1995:136). Anton E. Lawson (1995:168) memodifikasi fase yang digunakan untuk siklus belajar, "The Learning Cycle is a method of instruction that consist of three phase called exploration, term introduction, and concept application".

Pada perkembangan selanjutnya di tahun 1980, Biological Science Curriculum Study (BSCS) mengembangkan tiga fase siklus tersebut menjadi lima fase yang dikenal dengan Learning Cycle $5 E$ yang meliputi engagement, exploration, explanation, elaboration, dan evaluation (Trowbridge \& Bybee, 1990:317; Chiappetta \& Koballa, 2010:129; Brown \& Abell, 2007:58). Sesuai dengan perkembangan kurikulum, model Learning Cycle tidak terhenti pada lima fase saja, Arthur Eisenkraft mengembangkan menjadi tujuh fase. "Research on how people learn and the incorporation of that research into 
lesson plans and curriculum development demands that the $5 E$ model be expanded to a $7 E$ model" (Eisenkraft, 2003:56) menyatakan bahwa penelitian tentang bagaimana orang belajar dan hubungan terhadap penelitian mengenai rencana pembelajaran dan pengembangan kurikulum membutuhkan adanya pengembangan model $5 E$ menjadi model 7E. Pengembangan model Learning Cycle yang sesuai dengan National Science Teachers Association (NSTA) dari $5 E$ menjadi $7 E$ meliputi elicit, engage, explore, explain, elaborate, evaluate, dan extend (Eisenkraft, 2003:57; Chiappetta \& Koballa, 2010:129) disajikan pada Gambar 1 berikut.

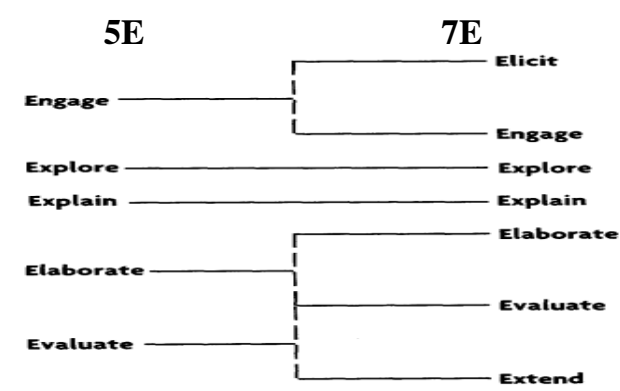

\section{Gambar 1.}

Pengembangan Learning Cycle 5E menjadi Learning Cycle $7 E$

Fase engage diperluas menjadi dua fase yaitu elicit dan engage sedangkan pada fase elaborate dan evaluate berkembang menjadi elaborate, evaluate, dan extend. Pengembangan ini bukan dimaksudkan untuk menambah unsur kompleksitas, namun untuk memastikan bahwa guru tidak menghilangkan unsur-unsur penting dalam proses pembelajaran.

Elicit bermakna menggali pengetahuan awal yang dimiliki siswa sebagai starting point oleh guru untuk memulai pembelajaran. Yenilmez \& Ersoy (2008:50) menyatakan fase elicit bertujuan mendatangkan atau memunculkan kembali informasi lama dan pengalaman belajar perlu dilakukan untuk menciptakan latar belakang yang kuat untuk fase lainnya. Kegiatan pada engage dimulai dengan menarik perhatian siswa untuk memulai pelajaran. Siswa terlibat untuk berpikir tentang topik dan mengajukan pertanyaan mereka sendiri serta mendefinisikan masalah dan brainstorming dalam suatu kasus (Yenilmez \& Ersoy, 2008:51). Fase yang membawa siswa untuk memperoleh pengetahuan dengan pengalaman langsung yang berhubungan dengan konsep yang akan dipelajari.

Pada fase explore siswa memiliki kesempatan untuk mengobservasi, menyimpan data, mengisolasi variabel, merancang dan merencanakan penyelidikan, membuat grafik, membangun hipotesis, dan mengorganisir temuan siswa berdasarkan ide masing-masing siswa (Eisenkraft, 2003:57). Fase explain, dimana siswa diperkenalkan pada konsep, hukum, dan teori baru. Siswa menyimpulkan dan mengemukakan hasil temuannya yang diperoleh pada fase sebelumnya. Tahap ini guru membimbing siswa untuk menjelaskan hasil eksplorasi mereka (Eisenkraft, 2003:58).

Fase elaborasi bertujuan memberi kesempatan kepada siswa untuk menerapkan atau mengaplikasikan pengetahuan mereka ke dalam situasi yang baru, dimana termasuk munculnya pertanyaan atau hipotesis baru untuk dieksplorasi, serta menghubungkan permasalahan baru untuk dipecahkan oleh siswa (Eisenkraft, 2003:58). Pada fase evaluasi, guru menilai keterampilan berpikir kritis siswa serta memberikan kesempatan mengevaluasi kemajuan siswa untuk mencapai pembelajaran. Hal tersebut sejalan dengan yang diungkapkan oleh Trowbridge \& Bybee (1990:319), "This is also the important opportunity for students to use the skills they have acquired and evaluate their understanding”. Eisenkraft (2003:59) menyatakan tahap extend secara eksplisit mengingatkan guru tentang pentingnya bagi siswa untuk berlatih transfer belajar. Guru perlu memastikan pengetahuan telah diterapkan dalam konteks yang baru dan tidak terbatas pada elaborasi sederhana.

Hartono (2013:60) berpendapat Learning Cycle 7E tidaklah dirancang untuk membantu guru memberikan banyak informasi kepada siswa namun Learning Cycle $7 E$ lebih membantu siswa untuk mengembangkan kemampuan berpikir, pemecahan masalah, dan kemampuan intelektual. Ditegaskan oleh Eisenkraft (2003:59) bahwa tujuan model Learning Cycle $7 E$ ini adalah menekankan pentingnya peningkatan memunculkan pemahaman sebelumnya yang telah dimiliki siswa dan kemudian memperluas atau mentransfer belajar ke dalam suatu konsep dan situasi yang baru.

\section{Aktivitas Siswa}

Indikator yang menandakan bahwa ada keinginan siswa untuk belajar adalah adanya aktivitas siswa dalam pembelajaran. Aktivitas belajar adalah aktivitas yang bersifat fisik (jasmani) maupun mental (rohani), tanpa aktivitas, belajar tidak mungkin berlangsung dengan baik. Aktivitas dalam proses pembelajaran merupakan rangkaian kegiatan yang meliputi keaktifan siswa dalam mengikuti pelajaran, berpikir, membaca, dan segala sesuatu yang menunjang prestasi belajar (Sardiman, 2014:100).

Paul B. Diedrich (dalam Sardiman, 2014:101) menggolongkan aktivitas belajar siswa dalam pembelajaran sebagai proses belajar meliputi visual activities, oral 
activities, listening activities, writing activities, drawing activities, motor activities, mental activities, dan emosional activities dalam proses belajar melalui interaksi dengan lingkungannya yang mengakibatkan perubahan perilaku dalam diri siswa.

\section{Keterampilan Berpikir Kritis}

Keterampilan berpikir merupakan salah satu kecakapan hidup (life skill) yang perlu dikembangkan selama proses pendidikan. Selain itu keterampilan berpikir juga sebagai sarana untuk mencapai tujuan pendidikan yaitu agar siswa mampu memecahkan masalah taraf tingkat tinggi (Nasution, 2008:173). Kemampuan seseorang untuk dapat berhasil dalam kehidupannya antara lain ditentukan oleh keterampilan berpikirnya, terutama dalam memecahkan masalah-masalah kehidupan yang dihadapinya. Hal tersebut dikarenakan saat ini banyak sekali fenomena dalam kehidupan sehari-hari yang perlu dikritisi, oleh karena itu sekolah harus mengajarkan cara berpikir yang benar sejak dari jenjang pendidikan SD.

John Dewey (dalam Fisher, 2007:2) mendefinisikan berpikir kritis yaitu pertimbangan yang aktif, persisten (terus menerus), dan teliti mengenai sebuah keyakinan atau bentuk pengetahuan yang diterima begitu saja dipandang dari sudut alasan-alasan yang mendukungnya dan kesimpulan-kesimpulan lanjutan yang menjadi kecenderungannya. Ennis (1985:45) menyatakan "Critical thinking is reasonable, reflective thinking that is focused on deciding what to believe or do", berpikir kritis adalah pemikiran yang reflektif dan masuk akal (berdasarkan nalar) yang berfokus untuk memutuskan apa yang mesti dipercaya atau dilakukan. Reflektif artinya mencari dengan sadar dan tegas kemungkinan solusi yang terbaik sedangkan masuk akal berarti berpikir didasarkan atas fakta-fakta untuk menghasilkan keputusan yang terbaik.

Berdasarkan uraian di atas maka dapat disimpulkan bahwa keterampilan berpikir kritis merupakan kemampuan seseorang untuk menggunakan nalar atau pemikiran yang masuk akal yang disertai dengan daya kritis terhadap segala sesuatu yang dialami kemudian mencari pemecahannya atau untuk membuat keputusan yang bijaksana.

Ennis (1985:46) mengembangkan keterampilan berpikir kritis menjadi 12 indikator yang dikelompokkan ke dalam lima kategori kelompok keterampilan berpikir kritis.
Tabel 1.

Indikator Keterampilan Berpikir Kritis Ennis

\begin{tabular}{|c|c|}
\hline Kelompok & Indikator \\
\hline Memberikan & a. Memfokuskan pertanyaan \\
\hline penjelasan & b. Menganalisis argumen \\
\hline sederhana & c. Bertanya dan menjawab pertanyaan \\
\hline $\begin{array}{l}\text { (elementary } \\
\text { clarification) }\end{array}$ & $\begin{array}{l}\text { tentang suatu penjelasan atau } \\
\text { pertanyaan }\end{array}$ \\
\hline Membangun & d. Mempertimbangkan kredibilitas \\
\hline keterampilan & suatu sumber \\
\hline dasar (basic & e. Mengamati dan mempertimbangkan \\
\hline support) & suatu laporan observasi \\
\hline Menyimpul- & f. Mendeduksi atau \\
\hline $\begin{array}{l}\text { Kan } \\
\text { (inference) }\end{array}$ & $\begin{array}{l}\text { g. Menginduksi dan } \\
\text { g. Masil deduKsi }\end{array}$ \\
\hline $\begin{array}{l}\text { Memberikan } \\
\text { penjelasan }\end{array}$ & $\begin{array}{l}\text { mempertimbangkan hasil induksi } \\
\text { h. Membuat dan menentukan hasil } \\
\text { pertimbangan }\end{array}$ \\
\hline $\begin{array}{l}\text { lanjut } \\
\text { (advance }\end{array}$ & $\begin{array}{l}\text { i. Mendefinisikan istilah dan } \\
\text { mempertimbangkan suatu definisi }\end{array}$ \\
\hline clarification) & j. Mengidentifikasi asumsi-asumsi \\
\hline Mengatur & k. Menentukan suatu tindakan \\
\hline strategi dan & 1. Berinteraksi dengan orang lain \\
\hline taktik & \\
\hline $\begin{array}{l}\text { (strategy and } \\
\text { tactics) }\end{array}$ & \\
\hline
\end{tabular}

\section{E. Pembelajaran IPS Berbasis Model Learning Cycle $7 E$}

Hubungan antara model Learning Cycle 7E dengan keterampilan berpikir kritis dalam pembelajaran IPS adalah melalui Learning Cycle $7 E$ maka akan memberikan kesempatan yang seluas-luasnya bagi siswa untuk terlibat aktif dalam pembelajaran dan mengembangkan kemampuan berpikir kritis serta berbuat. Pembelajaran IPS akan menjadi lebih bermakna karena apa yang dipelajari siswa dari awal hingga akhir proses pembelajaran menyentuh kehidupan sehari-hari siswa. Ketujuh fase pada model Learning Cycle $7 E$ diyakini dapat menjembatani melatihkan keterampilan berpikir kritis siswa karena akan menumbuhkan kemandirian siswa sejak dini dan mempersiapkan siswa untuk belajar memecahkan permasalahan yang dihadapi di lingkungan masyarakat.

Berdasarkan uraian di atas, aspek keterampilan berpikir kritis yang ditinjau dalam penelitian ini diadopsi dari indikator keterampilan berpikir kritis Ennis (1985) yang disesuaikan dengan kebutuhan dan karakteristik siswa pada jenjang sekolah dasar beserta kegiatan pada tiap fase model Learning Cycle $7 E$ yang secara jelas disajikan pada Tabel 2. 
Tabel 2.

Aspek/ Subindikator Keterampilan Berpikir Kritis yang Ditinjau

\begin{tabular}{|c|c|}
\hline $\begin{array}{c}\text { Fase } \\
\text { Learning } \\
\text { Cycle } 7 E\end{array}$ & $\begin{array}{l}\text { Aspek/Subindikator Keterampilan } \\
\text { Berpikir Kritis yang Ditinjau }\end{array}$ \\
\hline Elicit & $\begin{array}{l}\text { Memfokuskan pertanyaan } \\
\text { - Memfokuskan pemikiran dengan } \\
\text { mengajukan pertanyaan ilmiah dari suatu } \\
\text { penjelasan, fenomena atau tantangan }\end{array}$ \\
\hline Engage & $\begin{array}{l}\text { Mengenal masalah } \\
\text { - Mengidentifikasi masalah dari } \\
\text { suatu pernyataan atau fenomena sosial }\end{array}$ \\
\hline Explore & $\begin{array}{l}\text { Mempertimbangkan kredibilitas suatu } \\
\text { sumber } \\
\text { Mengumpulkan atau menyusun } \\
\text { informasi yang diperlukan }\end{array}$ \\
\hline Explain & $\begin{array}{l}\text { Mengidentifikasi asumsi-asumsi } \\
\text { - Membedakan antara sebab dan } \\
\text { akibat }\end{array}$ \\
\hline Elaborate & $\begin{array}{l}\text { Berinteraksi dengan orang lain } \\
\text { Menggunakan argumen }\end{array}$ \\
\hline Evaluate & $\begin{array}{l}\text { Menginduksi dan mempertimbangkan } \\
\text { hasil induksi } \\
\text { - Menarik kesimpulan }\end{array}$ \\
\hline Extend & $\begin{array}{l}\text { Menentukan suatu tindakan atau } \\
\text { keputusan } \\
\text { - Menghasilkan pemecahan masalah } \\
\text { terhadap suatu permasalahan sosial }\end{array}$ \\
\hline
\end{tabular}

Ketujuh indikator keterampilan berpikir kritis di atas penting untuk diimplementasikan dalam pembelajaran karena dengan indikator tersebut dapat melatih siswa untuk berpikir secara masuk akal dan reflektif guna menghasilkan suatu keputusan yang dapat mereka percaya atau lakukan terhadap permasalahan yang dijumpainya dalam kehidupan sehari-hari.

\section{METODE PENELITIAN}

Jenis penelitian ini merupakan penelitian pengembangan yang menekankan pada pengembangan perangkat pembelajaran IPS berbasis model Learning Cycle $7 E$ untuk meningkatkan aktivitas dan keterampilan berpikir kritis siswa kelas IV sekolah dasar. Subjek dalam penelitian ini adalah perangkat pembelajaran berbasis model Learning Cycle $7 E$ yang dikembangkan dan diimplementasikan pada 21 siswa kelas IV SDN Piasa Wetan tahun pelajaran 2015/2016 yang terlebih dahulu dilakukan uji coba terbatas pada sekolah lain.

Prosedur pengembangan perangkat pembelajaran pada penelitian ini menggunakan model pengembangan instruksional dari Thiagarajan, Semmel, \& Semmel (1974:5) yang terdiri dari empat tahap dan dikenal dengan model 4D (Four-D Model) yaitu define (tahap pendefinisian), design (tahap perancangan), develop (tahap pengembangan), dan disseminate (tahap penyebaran).
Dalam pengembangan perangkat ini hanya menggunakan tiga tahapan $3 D$, yaitu define, design, dan develop, tidak dilakukannya tahap disseminate dikarenakan keterbatasan waktu, biaya, dan tenaga.

Uji coba dilaksanakan dengan menggunakan desain penelitian One Group Pretest-Posttest Design (Thiagarajan, Semmel, \& Semmel, 1974:150; Arikunto, 2006:85). Desain ini dilakukan dengan membandingkan hasil pretes (pengujian awal sebelum menerima perlakuan) dengan hasil postes (pengujian akhir setelah menerima perlakuan) pada kelompok yang diujicobakan. Desain uji coba yang digunakan ditunjukkan sebagai berikut.

\section{$\mathrm{O}_{1} \mathrm{X}_{\mathrm{O}_{2}}$}

Keterangan:

$\mathrm{O}_{1}=$ Pretest sebelum perlakuan

$\mathrm{X}=$ Treatment berupa pembelajaran IPS berbasis Learning

Cycle $7 E$

$\mathrm{O}_{2}=$ Posttest sesudah perlakuan

Adapun teknik pengumpulan data dalam penelitian ini dilakukan dengan cara observasi, pemberian tes, dan angket. Instrumen penelitian yang digunakan adalah lembar validasi perangkat pembelajaran, lembar pengamatan keterlaksanaan RPP, lembar angket respon siswa, lembar penilaian keterbacaan BAS dan LKS, lembar penilaian aktivitas siswa, dan lembar tes keterampilan berpikir kritis.

Data yang telah diperoleh kemudian dianalisis secara deskriptif kualitatif dan deskriptif kuantitatif. Teknik analisis data yang digunakan dalam penelitian ini meliputi: analisis validitas perangkat pembelajaran, analisis keterlaksanaan RPP, analisis respon siswa, analisis keterbacaan BAS dan LKS, analisis LPAS, dan analisis TKBK.

\section{HASIL DAN PEMBAHASAN}

\section{A. Kevalidan}

Secara keseluruhan perangkat pembelajaran yang dikembangkan layak digunakan dengan sedikit revisi atau perbaikan berdasarkan saran dari para validator. Rekap hasil validasi terhadap perangkat pembelajaran berbasis model Learning Cycle 7E berupa RPP, LKS, BAS, LPAS, dan TKBK dari para validator tersaji pada Gambar 2 di bawah ini. 


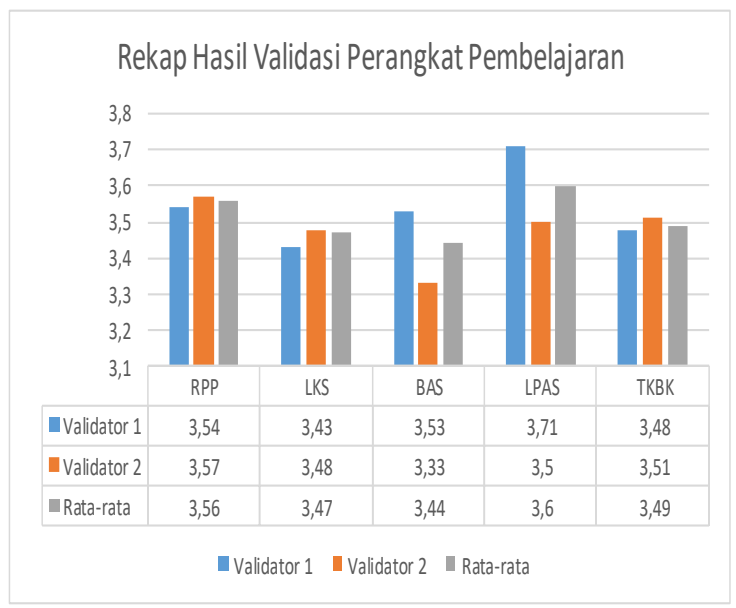

Gambar 2.

Diagram Rekap Hasil Validasi Perangkat Pembelajaran oleh Validator

Berdasarkan rata-rata penilaian dari kedua validator pada Gambar 2 di atas dapat diketahui bahwa RPP, LKS, BAS, dan TKBK yang dikembangkan berada pada kategori baik/valid. Sedangkan LPAS yang dikembangkan berada pada kategori sangat valid yaitu dengan nilai validasi sebesar 3,60. Oleh karena itu, perangkat pembelajaran yang dikembangkan telah memenuhi kriteria kevalidan sebuah kelayakan perangkat pembelajaran.

\section{B. Kepraktisan}

Kriteria kepraktisan perangkat pembelajaran terlihat dari keterlaksanaan RPP sebesar 100\% dan kategori keterlaksanaan RPP sangat baik sebesar 3,63. Pengamatan keterlaksanaan RPP yang dilakukan membuktikan bahwa tujuan model Learning Cycle $7 E$ adalah menekankan pentingnya peningkatan memunculkan pemahaman sebelumnya yang telah dimiliki siswa dan kemudian memperluas atau mentransfer belajar ke dalam suatu konsep dan situasi yang baru (Eisenkraft, 2003:59).

Adanya respon siswa terhadap perangkat pembelajaran maupun terhadap proses pembelajaran mengindikasikan bahwa perangkat pembelajaran praktis atau mudah digunakan. Respon siswa sangat kuat yaitu sebesar 94,04\% yang menandakan bahwa respon siswa positif serta tingkat keterbacaan BAS sebesar 77,5 dan keterbacaan LKS sebesar 77,5 masuk kategori mudah.

Pemilihan model Learning Cycle $7 E$ ini memang tepat karena mampu menjadikan siswa merasa senang dengan kegiatan pembelajaran yang dilakukan. Hal itu terbukti dengan hasil pengukuran respon siswa yang menghasilkan respon yang sangat baik. Hal itu sejalan dengan pendapat Muijs \& Reynold (2008:98) yang menyatakan bagi konstruktivis, belajar ialah pencarian makna yaitu keterlibatan siswa dalam pembelajaran haruslah dimaksimalkan untuk menemukan, membangun sendiri secara aktif pengetahuan dengan menggunakan pengetahuan awal yang telah dimiliki siswa sehingga wajar jika siswa sangat antusias dalam kegiatan pembelajaran yang telah berlangsung.

\section{Keefektifan}

Keefektifan perangkat pembelajaran digunakan untuk membuktikan apakah model perangkat pembelajaran mampu mencapai tujuan yang telah ditetapkan atau tidak. Dalam penelitian ini, keefektifan perangkat pembelajaran ditinjau dari peningkatan aktivitas dan keterampilan berpikir kritis siswa. Indikator aktivitas yang dikembangkan dalam penelitian ini didasarkan pada penggolongan aktivitas menurut Paul B. Diedrich (dalam Sardiman, 2014:101) yaitu visual activities, oral activities, listening activities, writing activities, mental activities, dan emotional activities. Berikut disajikan persentase aktivitas siswa untuk setiap indikator aktivitas siswa.

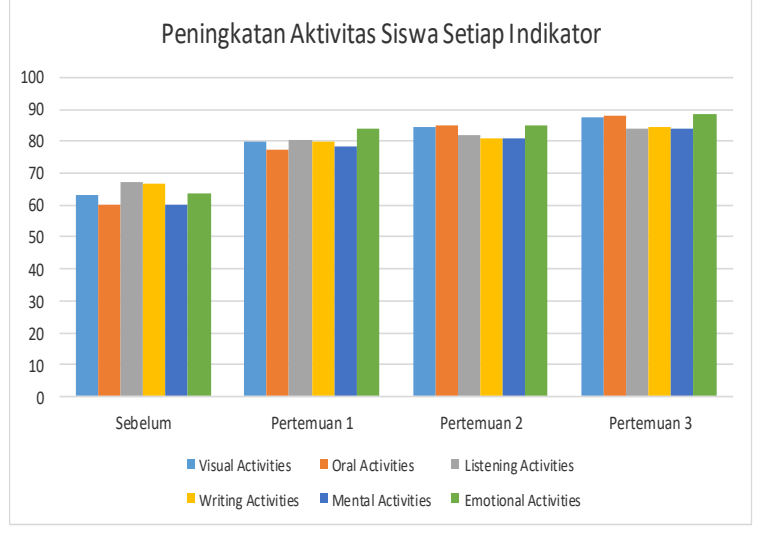

Gambar 3.

Diagram Peningkatan Aktivitas Siswa Setiap Indikator

Sedangkan peningkatan aktivitas siswa setiap pertemuan disajikan pada grafik berikut.

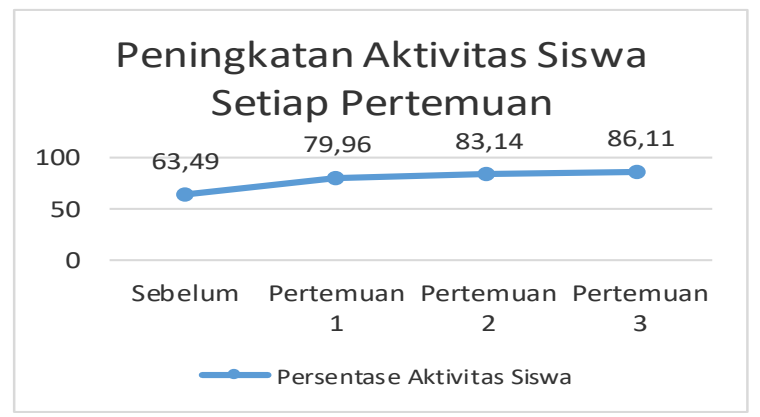

Gambar 4.

Grafik Peningkatan Aktivitas Siswa Setiap Pertemuan 


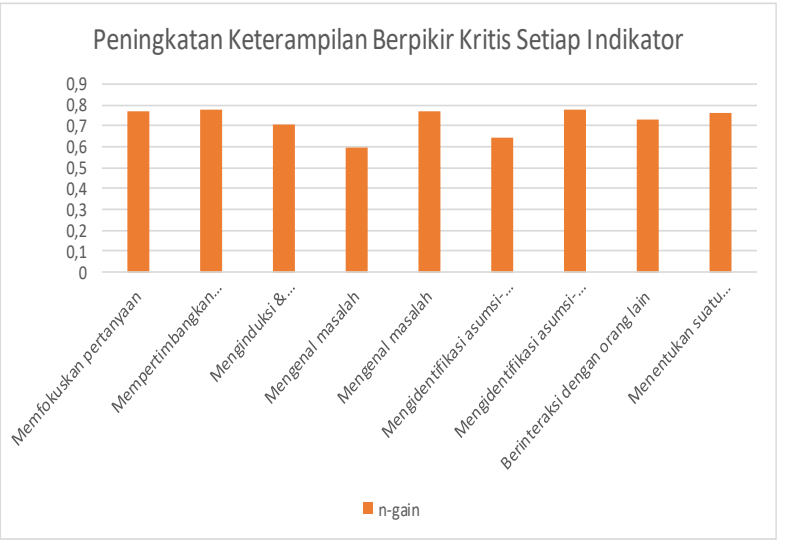

Gambar 5.

Diagram Peningkatan Keterampilan Berpikir Kritis Siswa

Berdasarkan kedua gambar di atas dapat dapat Simpulkan aktivitas siswa dalam penelitian ini mengalami peningkatan yang signifikan karena siswa dilibatkan langsung dalam penemuan informasi sehingga tercipta belajar bermakna, hal tersebut sesuai dengan pendapat Ausubel yaitu proses pembelajaran haruslah dikaitkan dengan informasi baru pada konsep-konsep relevan yang terdapat dalam struktur kognitif seseorang. Berdasarkan teori ini, siswa dijembatani untuk menanamkan pengetahuan baru sehingga sangat diperlukan pengetahuanpengetahuan awal yang sudah dimiliki siswa yang terkait dengan konsep yang akan siswa pelajari (Trianto, 2011:34). Ketujuh fase model Learning Cycle $7 E$ yang diterapkan dalam pembelajaran memiliki kelebihan seperti yang diungkap Shoimin (2014:61) yaitu mampu merangsang siswa untuk dilibatkan secara aktif dalam pembelajaran karena akan meningkatkan motivasi belajar siswa yang pada akhirnya akan meningkatkan keterampilan berpikir kritis siswa.

Peningkatan keterampilan berpikir kritis siswa dari sebelum dan setelah diberikan perlakuan atas pembelajaran berbasis model Learning Cycle $7 E$ diperoleh dari nilai pretest dan nilai posttest yang kemudian dianalisis untuk mencari nilai gain keterampilan berpikir kritis. Besarnya peningkatan nilai gain keterampilan berpikir kritis siswa disajikan pada Gambar 5 sebagai berikut.

Berdasarkan gambar di atas diperoleh bahwa 6 siswa berada pada gain sedang dan 15 siswa berada dalam gain tinggi. Peningkatan keterampilan berpikir kritis juga dianalisis berdasarkan indikator soal keterampilan berpikir kritis yang divisualisasikan pada Gambar 6 .

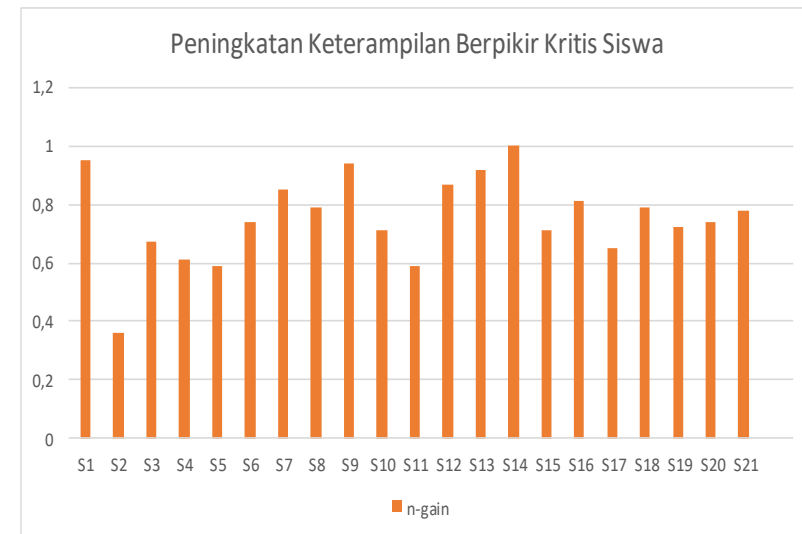

Gambar 6.

Diagram Peningkatan Keterampilan Berpikir Kritis Setiap Indikator

Berdasarkan Gambar 6. diperoleh rata-rata peningkatan keterampilan berpikir kritis tiap indikator sebesar 0,72 dengan kategori $n$-gain tinggi. Peningkatan keterampilan berpikir kritis yang terjadi disebabkan adanya pemrosesan informasi yang efektif. Gagne (1979) menegaskan bahwa pemrosesan informasi yang diterima ditransfer secara keseluruhan dari lingkungan ke panca indera kemudian masuk ke dalam suatu sensory register otak kita sebagai stimulus atau rangsangan. Pada model Learning Cycle $7 E$, stimulus diterima siswa pada fase elicit dan engage, untuk dilakukan pengkodean melalui fase explore dan explain. Sedangkan fase elaborate, evaluate, dan extend digunakan untuk menindaklanjuti informasi baru tersebut sehingga dapat disimpan dalam memori jangka panjang.

\section{SIMPULAN DAN SARAN}

Berdasarkan hasil uji coba perangkat, analisis, diskusi, dan pembahasan yang telah dilakukan, maka diperoleh kesimpulan sebagai berikut.

1. Perangkat pembelajaran yang dikembangkan layak untuk diimplementasikan karena telah memenuhi kriteria kevalidan, kepraktisan, dan keefektifan suatu perangkat pembelajaran.

2. Adanya peningkatan aktivitas dan keterampilan berpikir kritis siswa kelas IV sekolah dasar setelah diterapkannya perangkat pembelajaran IPS berbasis model Learning Cycle 7E.

Adapun saran yang diajukan sebagai berikut.

1. Guru pada sekolah lain dapat menerapkan model Learning Cycle $7 E$ dalam pembelajaran IPS untuk meningkatkan aktivitas dan keterampilan berpikir kritis siswa kelas IV sekolah dasar berdasarkan perangkat pembelajaran yang telah dikembangkan. 
2. Disarankan kepada peneliti berikutnya kiranya dapat merancang penelitian lanjutan tentang model pembelajaran Learning Cycle $7 E$ yang lebih luas untuk mata pelajaran, materi pembelajaran, maupun keterampilan berpikir lainnya.

\section{DAFTAR PUSTAKA}

Arikunto, Suharsimi. (2006). Prosedur Penelitian Suatu Pendekatan Praktik Edisi Revisi VI. Jakarta: Rineka Cipta.

Brown, Patrick L. and Abell, Sandra K. (2007). "Examining the Learning Cycle". Science and Children. Vol. 44 No. 5 Summer 2007. pp. 58-59.

Bybee, R. W., Taylor, J. A., Gardner, A., Van Scotter, P., Powell, J. C., Westbrook, A., Landes N. (2006). The BSCS 5E Instructional Model: Origins, Effectiveness, and Applications. Colorado Springs: BSCS.

Chiappetta, Eugene L. and Koballa, Thomas R. (2010). Science Instruction in The Middle and Secondary School: Developing Fundamental Knowledge and Skills (Seventh Edition). Boston: Pearson Education, Inc.

Dwijananti, P. dan Yulianti, D. (2010). "Pengembangan Kemampuan Berpikir Kritis Mahasiswa Melalui Pembelajaran Problem Based Instruction pada Mata Kuliah Fisika Lingkungan”. Journal Pendidikan Fisika Indonesia. Vol. 6 Tahun 2010. hlm. 108-114.

Eisenkraft, Arthur. (2003). "Expanding the 5E Model: A Proposed 7E Model Emphasis 'Transfer of Learning' and the Importance of Eliciting Prior Understanding”. The Science Teacher. Vol. 70 No. 6 Summer 2003. pp. 56-59.

Ennis, Robert H. (1985). "A Logical Basis for Measuring Critical Thinking Skills". Educational Leadership. Vol. 43 No. 2 Summer 1985. pp. 44-48.

Fisher, Alec. (2007). Critical Thinking an Introduction. Cambridge: Cambridge University Press.

Gagne, N.L. and Berliner, D.C. (1979). Educational Psychology. Second Edition. Boston: Houghton Miff Lin Company.

Hartono. (2013). "Learning Cycle 7E Model to Increase Students Critical Thinking on Science". Jurnal Pendidikan Fisika Indonesia 9 (2013) 58-66. ISSN: 1693-1246.

Husamah dan Setyaningrum, Yanuar. (2013). Desain Pembelajaran Berbasis Pencapaian Kompetensi: Panduan Merancang Pembelajaran untuk Mendukung Implementasi Kurikulum 2013. Jakarta: Prestasi Pustakaraya.
Lawson, Anton E. (1995). Science Teaching and The Development of Thinking. California: Wadsworth, Inc.

Muijs, Daniel dan Reynolds, David. (2008). Effective Teaching: Teori dan Aplikasi. Yogyakarta: Pustaka Pelajar.

Nasution, S. (2008). Berbagai Pendekatan dalam Proses Belajar Mengajar. Jakarta: Bumi Aksara.

Nieveen, Nienke. (1999). Prototyping to Reach Product Quality. Dalam Akker, Jan et al., (Eds.), Design Approaches and Tools in Education and Training (pp.125-136). Kluwer Academic Publishers.

Rajabi, M., Hariadi, Eko., dan Buditjahjanto, Asto. (2015). "Pengembanagan Perangkat Pembelajaran Instalasi Sistem Operasi dengan Model Pembelajaran Berbasis Proyek". Jurnal Pendidikan Vokasi: Teori dan Praktek. Vol. 3 No. 1 Tahun 2015. pp. 48-54

Sanjaya, Wina. (2006). Strategi Pembelajaran Berorientasi Standar Proses Pendidikan. Jakarta: Kencana.

Sapriya. (2012). Pendidikan IPS: Konsep dan Pembelajaran. Bandung: Remaja Rosdakarya.

Sardiman. (2014). Interaksi dan Motivasi Belajar Mengajar. Jakarta: PT Raja Grafindo Persada.

Shoimin, Aris. (2014). 68 Model Pembelajaran Inovatif dalam Kurikulum 2013. Yogyakarta: Ar-Ruzz Media.

Thiagarajan, Sivasailam., Semmel, Dorothy S,. and Semmel, Melvyn I. (1974). Instructional Development for Training Teachers of Exceptional Children a Sourcebook. Washington: University of Minnesota.

Trianto. (2011). Mendesain Model Pembelajaran InovatifProgresif: Konsep Landasan dan Implementasinya pada Kurikulum Tingkat Satuan Pendidikan (KTSP). Jakarta: Kencana.

Trowbridge, Leslie W. dan Bybee, Rodger W. (1990). Becoming a Secondary School Science Teacher. Ohio: Merril Publishing Company.

Yenilmez, K. and Ersoy, M. (2008). "Opinion of Mathematics Teacher Candidate Toward Applying 7E Instructional Model on Computer Aided Instruction Environments". International Journal of Instruction. Vol. 1 No. 1. Summer 2008. pp. 49-60. 